\title{
World Red Cross and Red Crescent Day 1990
}

\author{
JOINT MESSAGE OF THE LEAGUE OF RED CROSS \\ AND RED CRESCENT SOCIETIES \\ AND THE INTERNATIONAL COMMITTEE OF THE RED CROSS*
}

Today is World Red Cross and Red Crescent Day. On this occasion, the International Committee of the Red Cross, the League of Red Cross and Red Crescent Societies, the 149 National Societies and their 250 million members launch this appeal:

\section{Protect human life and dignity}

In many parts of the world, the life and dignity of millions of women, men and children are threatened every day by armed conflicts and natural disasters.

It is impossible not to feel similar horror today at the arbitrary and senseless violence committed against so many people in the world.

It is impossible not to do everything in our power to protect life and to ease the suffering of those who, accidentally or unjustly, become the victims of natural disasters or man-made catastrophes.

In the name of all the people trapped in solitude and anguish, in their jail cells, hospitals, and camps for prisoners and refugees...

In the name of all those who are suffering from wounds, from the loss of a father or mother, of a husband, a wife, or a child, or who have seen in the ruins of their homes the loss of everything most dear to them...

In the name of all the forgotten victims of conflict and disaster, we call upon all citizens, peoples and governments of the world to:

* This message has been recorded by: Mr. Cornelio Sommaruga, President of the International Committee of the Red Cross (speaking in French, German and Italian); Dr. Mario Villarroel Lander, President of the League of Red Cross and Red Crescent Societies (speaking in Spanish); Mr. Pär Stenbäck, Secretary General of the League of Red Cross and Red Crescent Societies (speaking in English); Dr. Ahmad Abu-Goura, Chairman of the Standing Commission of the Red Cross and Red Crescent (speaking in Arabic). The recording (on $71 / 2$ reel tape or cassette) can be obtained from the Press Division of the International Committee of the Red Cross 


\section{Protect human life and dignity}

The life of every human being is unique and irreplaceable. The life of every human being must be respected and protected against the ravages of man and nature. Without such values and universal principles, there is no proper human life, society or civilization.

This is the firm conviction of the International Red Cross and Red Crescent Movement.

To protect human life and dignity worldwide, without regard to nationality, race, circumstance or political opinions and to do so regardless of influence or pressure, no matter where, no matter when.

This is the mission of our Movement. A mission founded on humanitarian principles and recognised by international law and customs.

Coming to the aid of people caught in the violence of armed conflict and other emergencies.

Visiting prisoners of war and other detainees, helping people to communicate with loved ones and reuniting families.

Helping people to face hurricanes, floods, fires, drought or other disasters that threaten individuals and their communities.

Saving in this way millions of lives through prevention, protection and assistance.

This is the daily work of the innumerable volunteers, delegates and leaders of the Red Cross and Red Crescent.

At a time when the opportunities for peace are so great, at a time when peoples are expressing with real determination their aspiration to freedom and fraternity.

\section{Let us refuse to accept the inevitability of suffering!} Let us refuse to remain indifferent to conflicts and disasters!

Let us build a common front for Humanity along with all those who believe that respect for human life and dignity should outweigh all other considerations.

\section{Let us choose humanity, and reject inhumanity!}

The International Red Cross and Red Cross Movement has already made this choice. 